\title{
Generation and characterization of a human single-chain fragment variable (scFv) antibody against cytosine deaminase from Yeast Alessandra Mallano ${ }^{1}$, Silvia Zamboni ${ }^{1}$, Giulia Carpinelli², Filippo Santoro ${ }^{2}$, Michela Flego ${ }^{1}$, Alessandro Ascione ${ }^{1}$, Mara Gellini ${ }^{1}$, Marina Tombesi ${ }^{1}$, Franca Podo $^{2}$ and Maurizio Cianfriglia*1
}

\author{
Address: ${ }^{1}$ Department of Therapeutic Research and Medicines Evaluation, Istituto Superiore di Sanità, Viale Regina Elena 299, Rome, Italy and \\ ${ }^{2}$ Department of Cell Biology and Neurosciences, Istituto Superiore di Sanità, Viale Regina Elena 299, 00161 Rome, Italy \\ Email: Alessandra Mallano - alessandra.mallano@iss.it; Silvia Zamboni - silvia.zamboni@iss.it; Giulia Carpinelli - giulia.carpinelli@iss.it; \\ Filippo Santoro - filippo.santoro@iss.it; Michela Flego - michela.flego@iss.it; Alessandro Ascione - alessandro.ascione@iss.it; \\ Mara Gellini - mara.gellini@iss.it; Marina Tombesi - marina.tombesi@iss.it; Franca Podo - franca.podo@iss.it; \\ Maurizio Cianfriglia* - maurizio.cianfriglia@iss.it \\ * Corresponding author
}

Published: 10 September 2008

BMC Biotechnology 2008, 8:68 doi:10.1 | 86/1472-6750-8-68

This article is available from: http://www.biomedcentral.com/l472-6750/8/68

(c) 2008 Mallano et al; licensee BioMed Central Ltd.

This is an Open Access article distributed under the terms of the Creative Commons Attribution License (http://creativecommons.org/licenses/by/2.0), which permits unrestricted use, distribution, and reproduction in any medium, provided the original work is properly cited.

\begin{abstract}
Background: The ability of cytosine deaminase $(C D)$ to convert the antifungal agent 5fluorocytosine (5-FC) into one of the most potent and largely used anticancer compound such as 5 -fluorouracil (5-FU) raised considerable interest in this enzyme to model gene or antibody directed enzyme-prodrug therapy (GDEPT/ADEPT) aiming to improve the therapeutic ratio (benefit versus toxic side-effects) of cancer chemotherapy. The selection and characterization of a human monoclonal antibody in single chain fragment (scFv) format represents a powerful reagent to allow in in vitro and in vivo detection of CD expression in GDEPT/ADEPT studies.
\end{abstract}

Results: An enzymatic active recombinant $C D$ from yeast $(y C D)$ was expressed in $E$. coli system and used as antigen for biopanning approach of the large semi-synthetic ETH-2 antibody phage library. Several scFvs were isolated and specificity towards $y C D$ was confirmed by Western blot and ELISA. Further, biochemical and functional investigations demonstrated that the binding of specific scFv with yCD did not interfere with the activity of the enzyme in converting 5-FC into 5FU.

Conclusion: The construction of libraries of recombinant antibody fragments that are displayed on the surface of filamentous phage, and the selection of phage antibodies against target antigens, have become an important biotechnological tool in generating new monoclonal antibodies for research and clinical applications. The $\mathrm{scFvH} 5$ generated by this method is the first human antibody which is able to detect $y C D$ in routinary laboratory techniques without interfering with its enzymatic function.

\section{Background}

The ability of cytosine deaminase (CD) to convert the clinically used antifungal agent 5-fluorocytosine (5-FC) into one of the most potent and largely used anticancer 
agent such as 5-fluorouracil (5-FU) raised considerable interest in this enzyme to design innovative anticancer therapies $[1,2]$. Therefore, CD-based enzyme/prodrug strategies are under investigation to model gene or antibody directed enzyme-prodrug therapy (GDEPT/ADEPT) for achieving high local concentration of 5-FU without significant systemic toxicity $[3,4]$. In in vivo animal model, the CD gene/enzyme which is not naturally expressed in mammals are first introduced into the cells of a tumour by specific antibodies [5-7], modified microorganisms such as bacteria and viruses or synthetic vectors (reviewed by Springer et al., 2007)[4]. When the discrimination between tumor and normal tissue enzyme levels is sufficient, 5-FC is given i.v., which is converted into 5-FU by $\mathrm{CD}$ within the tumor [8]. A convincing demonstration that such a complex system can be developed for clinical use requires evidence that each of the components of the gene/antibody complex functions by the mechanisms proposed [9]. This can be provided by well defined measurements including the concentration levels of the antibody-enzyme conjugate or de novo expressed enzyme, in plasma, tumor and normal tissues [10-12]. To allow the detection of $\mathrm{CD}$ expression at the protein level, we raised a human monoclonal antibody in single chain fragment $(\mathrm{scFv})$ format against a recombinant $\mathrm{CD}$ from yeast ( $\mathrm{yCD}$ ) proved to be functionally active in NMR and in in vitro studies to convert the antifungal drug 5-FC into the anticancer compound 5-FU. The specificity of the human scFv was confirmed by Western blot and ELISA analyses. With this antibody, yCD expression can now be monitored without interfering with its enzymatic function in GDEPT, ADEPT and other studies leading to the effect of the so called tumour amplified protein expression and targeting (TAPET) to localize in vitro and in vivo generation of the anticancer agent 5-FU [4].

\section{Results and discussion}

The CD/5-FC-based GDEPT or ADEPT are among the most studied strategies aiming to improve the therapeutic ratio (benefit versus toxic side-effects) of cancer chemotherapy. $\mathrm{CD}$ has the ability to deaminate the non toxic prodrug 5-FC into the highly toxic compound 5-FU. By inhibiting DNA synthesis this drug preferentially kills tumour cells. However, 5-FU has high gastrointestinal and hematological toxicities [2]. In contrast, the prodrug 5-FC is fairly nontoxic [13]. and CD is not naturally expressed in mammalian cells. Thus, the selectively guided $\mathrm{CD} / 5-\mathrm{FC}$ complex should minimize the toxic effects of 5-FU because the conversion of 5-FC to 5-FU should only occur within the tumor.

A convincing demonstration that this strategy can be developed for clinical use requires knowledge of specific parameters which may include the in in vivo monitoring of the CD complex. For this reason we have firstly con- structed a novel expression system for the production of a functionally active yCD. Subsequently a fully human antibody in scFv format not interfering with yCD activity was developed and analyzed.

\section{Expression and purification of yCD protein}

A functionally active $\mathrm{YCD}$ was generated by recombinant DNA technology. The gene encoding for $\mathrm{yCD}$ was amplified and inserted into the PQE30Xa expression vector which contained the lac promoter for protein induction and $6 \times$ His TAG sequence for purification (Fig. 1A). 500 base pairs band shown in Figure 1B corresponded to DNA fragment encoding for yCD obtained by PCR using specific primers. After TG1 E. coli bacterial strain transformation, several clones were isolated and proved suitable for yCD production. The clone exhibiting the best protein induction was further characterized. The yield of purified protein was about $10 \mathrm{mg} \mathrm{l}^{-1}$, using metal chelate affinity chromatography. The reliability of this novel expression system used for protein isolation and purification was confirmed by biochemical investigation showing that yCD migrated at the expected molecular weight of about $20 \mathrm{kDa}$ (Figure 1C).

\section{Selection and characterization of scFvH5 antibody specific for yCD}

To isolate phage-displayed specific antibodies, an aliquot of the human synthetic ETH-2 library containing approximately $1 \times 10^{12} \mathrm{cfu}$ phages was panned into Nunc-immunotubes coated with $10 \mu \mathrm{g} \mathrm{ml}^{-1}$ of purified yCD. Nonspecifically absorbed phages were removed by intensive washing. Specific bound phages were eluted, amplified and used for next panning as previously described [14]. By using this protocol, we were able to isolate a phage-antibody population specifically recognizing yCD protein after only three rounds of selection. Plating on agar of TG1 cells infected with a pool of phage antibodies from third selection allowed individual clones harboring phagemid to grow. Soluble scFvs derived from IPTG inducted colonies, were screened by ELISA and several of them proved to be specific for $y C D$ protein (Figure 2). One of the most reactive $\mathrm{scFv}$ antibody clone, named $\mathrm{H} 5$, was isolated and further characterized under biochemical and genetic aspects.

Western blot studies showed that scFvH5 recognizes a protein band of about $20 \mathrm{KDa}$ corresponding to the expected molecular weight of the purified $\mathrm{yCD}$ protein (see Fig. 2, inserted box). The genes encoding for variable regions of heavy $(\mathrm{VH})$ and light $(\mathrm{VL})$ chains of the scFvH5 were sequenced, and their corresponding amino acid aligned (Fig. 3) according to Pini et al., [15]. 


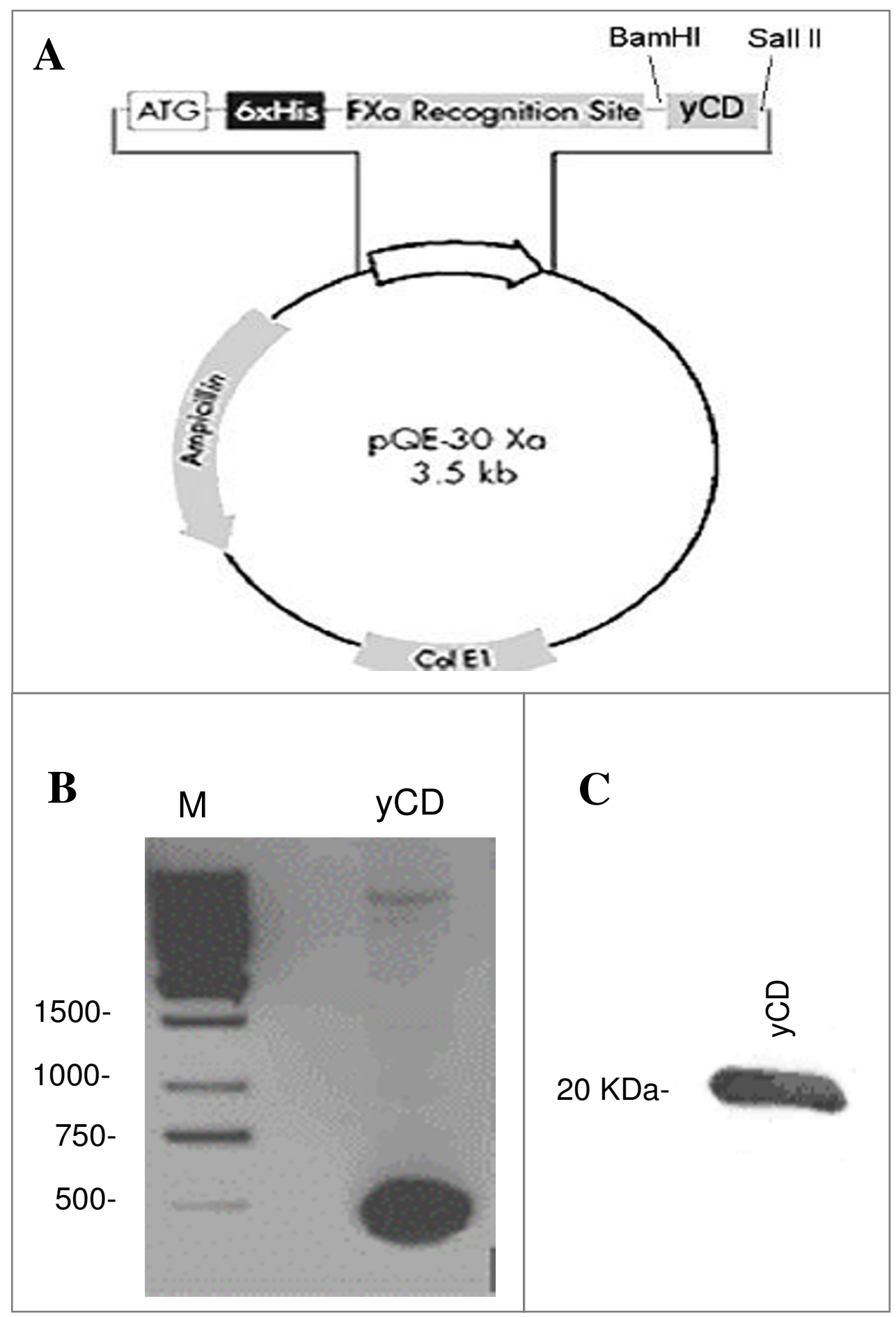

\section{Figure I}

Expression of recombinant yCD. In (A), is depicted a schematic representation of yCD expression vector, constructed by inserting the coding sequence for yCD into PQE30Xa plasmid, and expressed in TGI strain of $E$. coli. In (B) and (C) are shown respectively, the PCR-DNA fragment corresponding to the expected 500 bases pair encoding for yCD and the immuno-blot of the purified $y C D$ protein. 


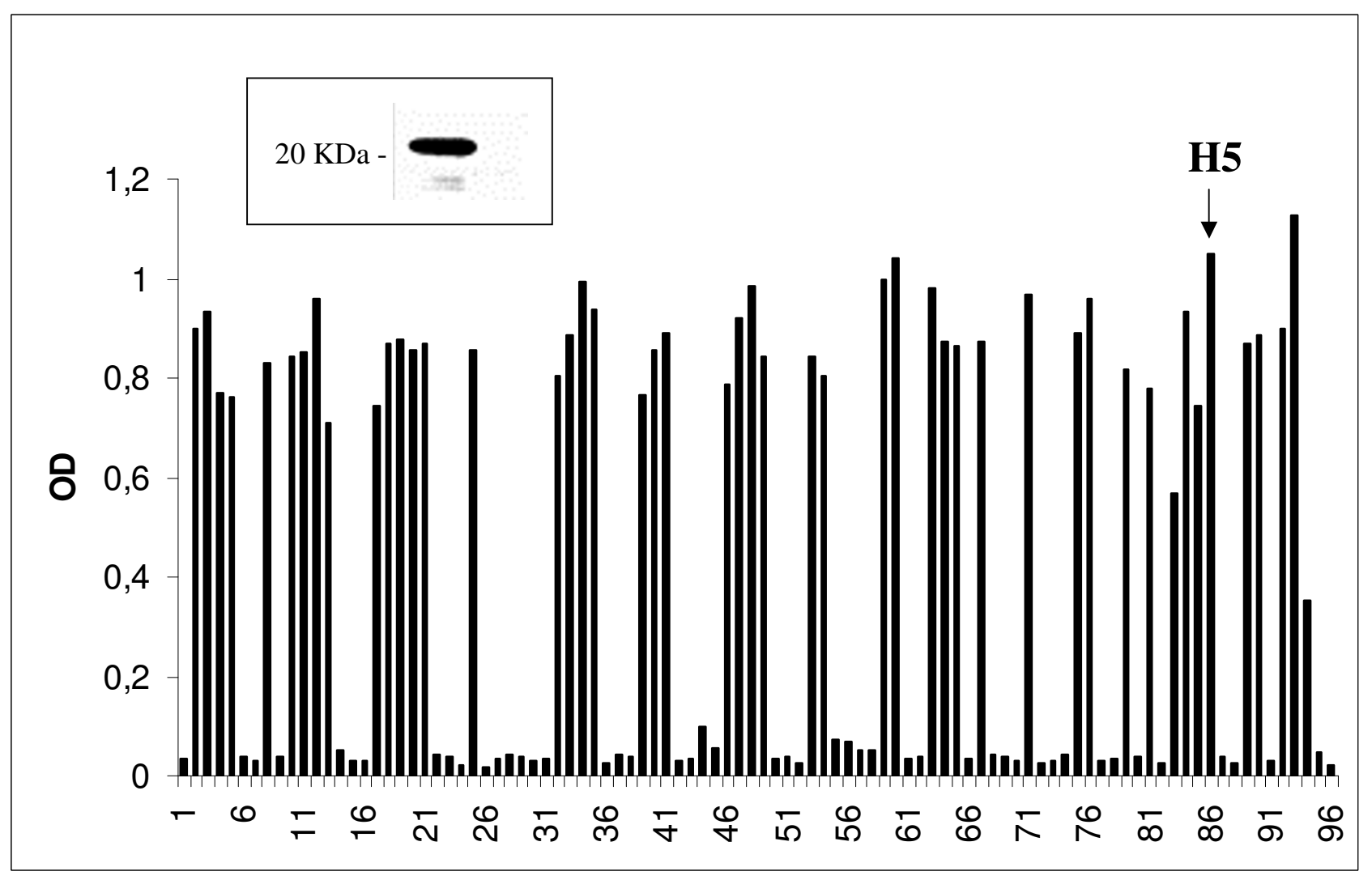

\section{Figure 2}

Selection of yCD-specific scFvs. IPTG inducted bacterial supernatants of individual colonies from the third round of the ETH-2 selection on yCD protein, were tested by ELISA in 96-well microtiter plates coated with the antigen. OD values higher than three fold the value of negative control are scored as positive. Negative and positive controls positioned in wells I-4 reacted as expected. In the inserted box, the Western blot of yCD protein detected by scFvH5 (one of the most reactive clones) is shown.

\section{Determination of yCD activity}

In order to determine the functional activity of the recombinant $y C D$, the ability of the enzyme to deaminate 5-FC was assessed by fluorine NMR. This approach allowed simultaneous detection of the substrate and the product without interference by other compounds. Figure 4 shows that after 90 min 5-FC was completely converted into 5$\mathrm{FU}$ in the presence of the $\mathrm{yCD}$. Absolute quantification of the product was obtained by adding a known amount of 5 -FU to the reaction mixture at the end of the experiment.

The specific yCD enzymatic activity was also assessed by spectrophotometric analysis in order to determine nanomolar concentrations of the reaction product. Figure $5 \mathrm{~A}$ shows the initial velocity of the reaction which is represented by direction coefficient of the line plotted placing concentration of formed 5-FU versus reaction time.

In order to assess if the enzymatic activity of yCD was affected by the presence of the scFvH5 an identical exper- iment was performed in presence of the antibody. Figure $5 \mathrm{~B}$ shows that the rate of product formation was similar to that with free $y C D$, suggesting that there was no apparent loss in enzyme activity as a result of binding with scFvH5. Identical results were obtained using the irrelevant scFvGO antibody (see Figure 5C).

\section{Cytotoxic assay}

Using an in vitro model constituted by human LoVo cells, we measured the enzymatic activity of the recombinant $\mathrm{yCD}$ protein in converting the antifungal agent 5-FC into the highly toxic anticancer compound 5-FU. In parallel we evaluated if co-incubation of the same reagents with scFvH5 affected yCD function. Figure 6A shows that 2.5 $\mu \mathrm{g} \mathrm{ml}^{-1}$ of yCD exerted a significative cell growth inhibition of the human carcinoma LoVo cells in the presence of 5 -FC concentration ranging from $1 \mathrm{mg} \mathrm{ml}^{-1}$ and $10 \mu \mathrm{g} \mathrm{ml}-$ 1 . In contrast, the co-incubation of $\mathrm{yCD}$ and 5 -FC with various concentration of scFvH5 did not interfere with the cytotoxic activity of de novo generated 5-FU (Figure 6B). 


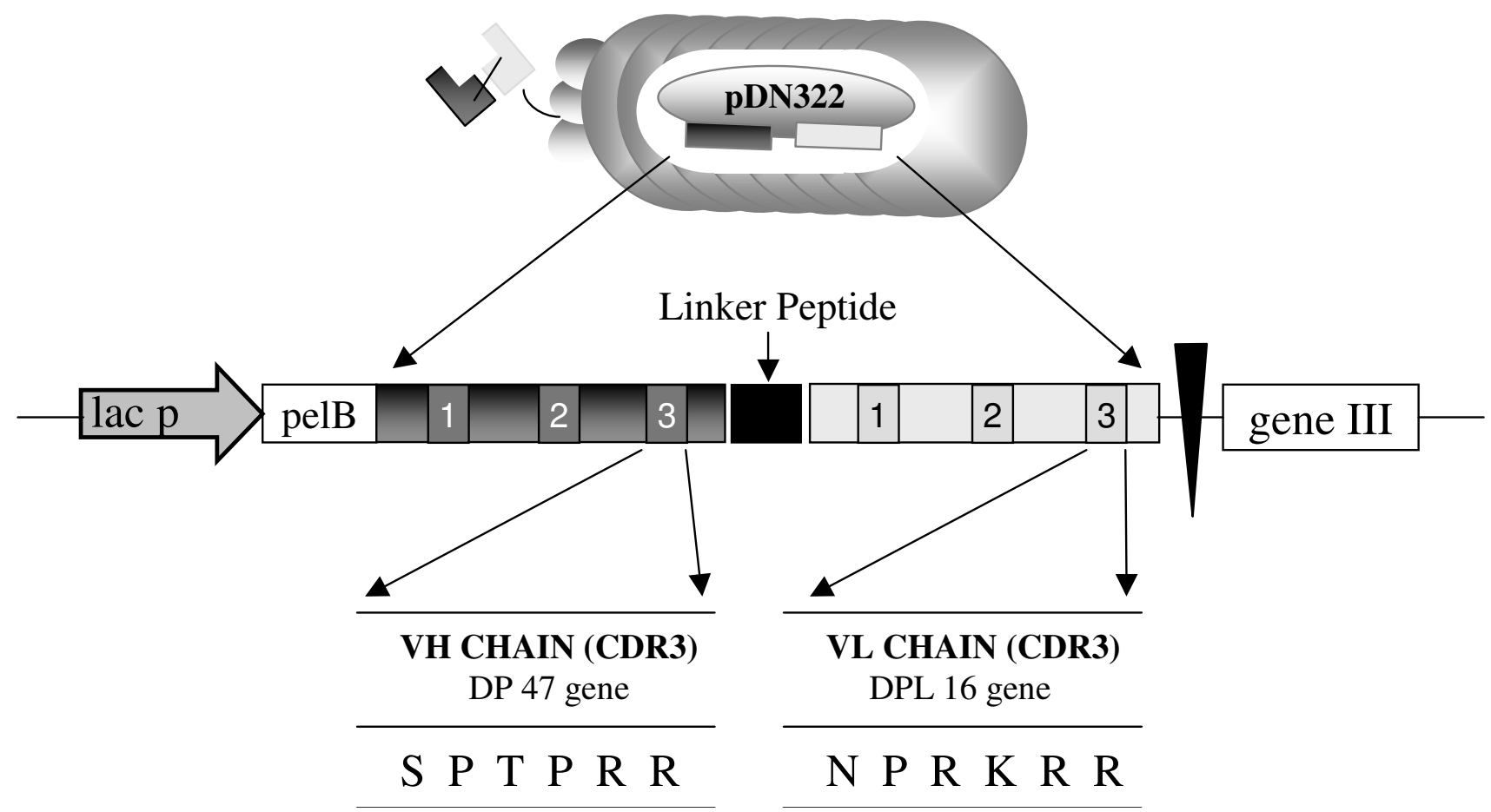

Figure 3

Sequence analysis of scFv $\mathbf{H 5}$ and genetic structure of phage antibody from ETH-2 library. The amino acid sequence of the CDR3 regions of the selected scFv H5 antibody are reported. A schematic representation of the scFv antibodies dislpayed on MI3 phage as plll fusion proteins is depicted.

The results above reported demonstrated that, yCD produced by the novel expression system here described acts as an active enzyme in converting 5-FC into the anticancer compound 5-FU. Moreover, the binding of the human

\section{A}

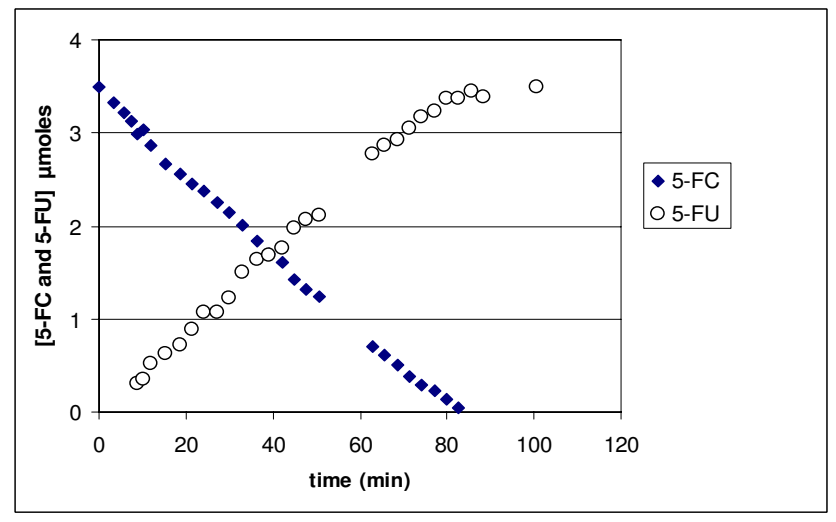

scFvH5 with yCD did not affect the enzyme function. In particular, our studies demonstrated that the presence of scFvH5 did not interfere with yCD in converting 5-FC or with the cytotoxic activity of de novo formed 5-FU.

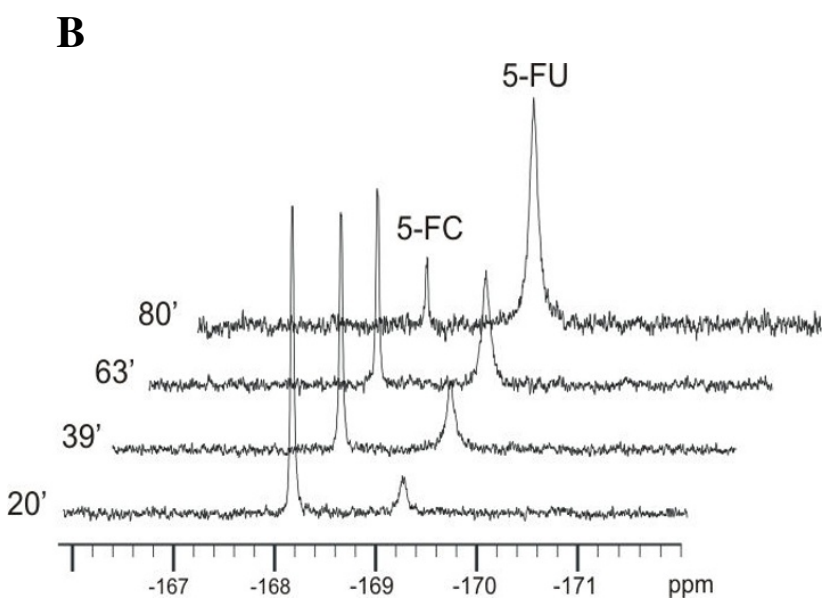

\section{Figure 4}

Functional analysis of yCD by ${ }^{19}$ F NMR study. In (A) and (B) are shown respectively, the 5-FU formation ( $\mu$ lmoles) due to the conversion of 5-FC by $y C D$ and representative spectra during the reaction at 20,39, 63 and 80 min. 
A

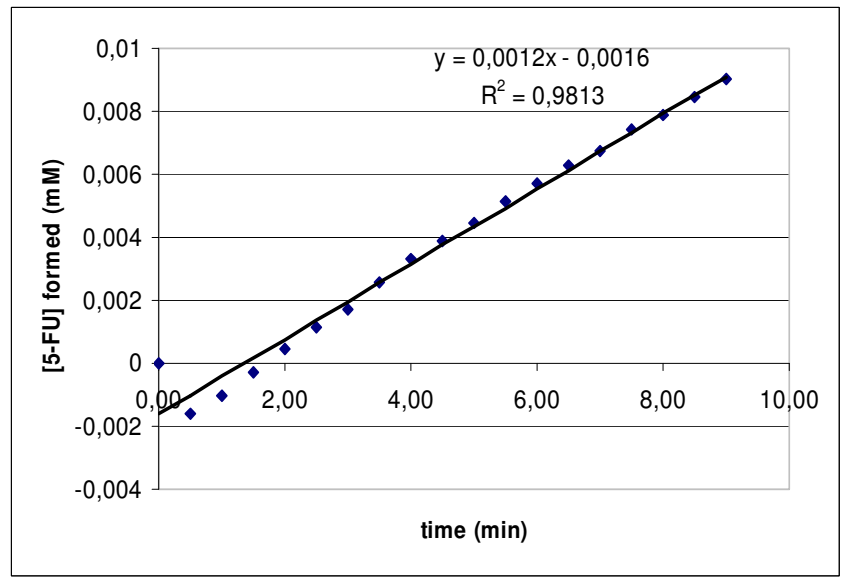

B

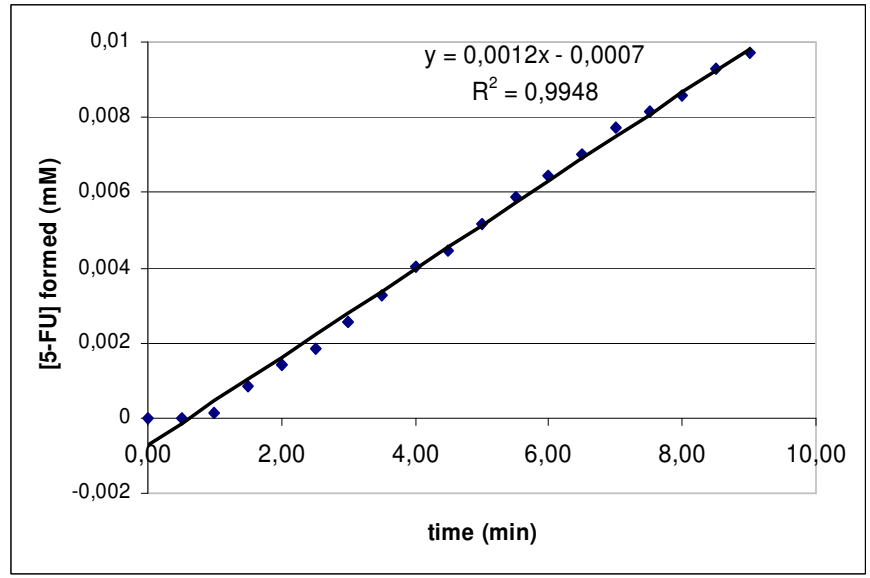

C

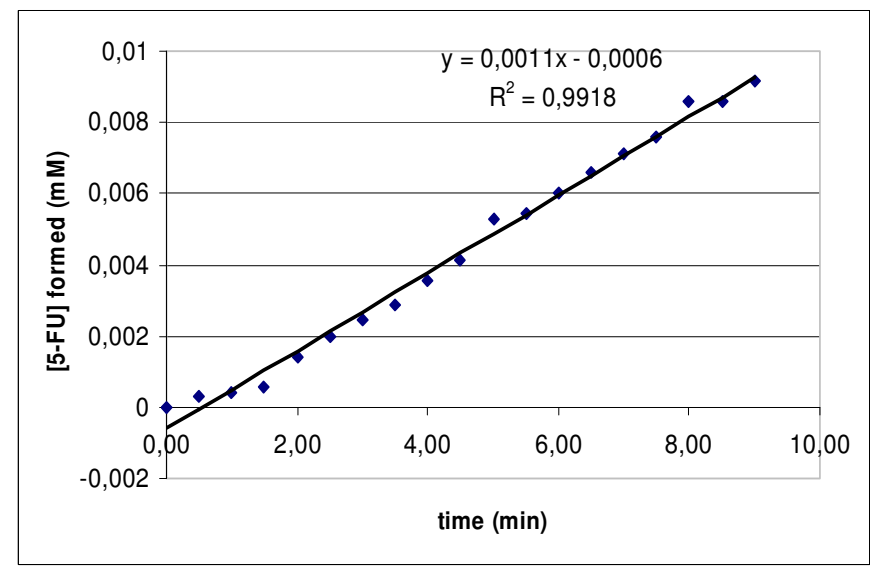

Figure 5

Spectrophotometry of yCD activity. In (A), are reported the values of de novo formed 5-FU (mM) obtained in presence of $y C D\left(0.5 \mu \mathrm{g} \mathrm{m}^{-1}\right)$ and $5-\mathrm{FC}(0.18 \mathrm{mM})$ during the first $9 \mathrm{~min}$ of the reaction. $\ln (B)$ and $(C)$ are reported the 5 -FU values obtained with identical reagents but in presence of $2 \mu \mathrm{g} \mathrm{ml}-1$ of the specific (scFvH5) or irrelevant (scFvGO) antibodies. Slope of lines represents starting speed of the reaction. Correlation coefficient $(R)$ indicates the strength and direction of the linear relationship between time and formed 5-FU.

\section{Conclusion}

The monoclonal antibody scFvH5 may be a very useful reagent for detection of CD expression in GDEPT/ADEPT studies. In fact, this $\mathrm{mAb}$ detects functional yCD either in ELISA or in Western blot studies (Figure 1 and 2) thus providing evidence that similar techniques may be extended to measure yCD levels in plasma, tumor and normal tissue samples. Since its particular genetic origin, the scFvH5 can be easily genetically engineered to construct a whole human antibody with a predefined IgG subclass, for selective removal of mAb-yCD conjugate from the circulation, without interfering with the enzyme function.

Differently with other mAbs to CD generated by hybridoma [5] or recombinant DNA technologies [16], the
scFvH5 is the first fully human monoclonal antibody in $\mathrm{scFv}$ format so far described which is able to detect $\mathrm{yCD}$ protein in different routinary laboratory techniques. Hence, this antibody may represents an excellent candidate for in vivo detection and measurement of the $\mathrm{CD}$ complex in the future development of CD-based selectively guided tumor therapy.

\section{Methods}

\section{Antibodies and reagents}

The characteristics of the scFvGO used in this study as scFv irrelevant antibody were previously described [17]. AntiFlag M2 and anti-polyhistidine antibodies were purchased from Sigma (St Louis, MO, USA). The goat antimouse HRP-conjugated polyclonal antibody was pur- 
A

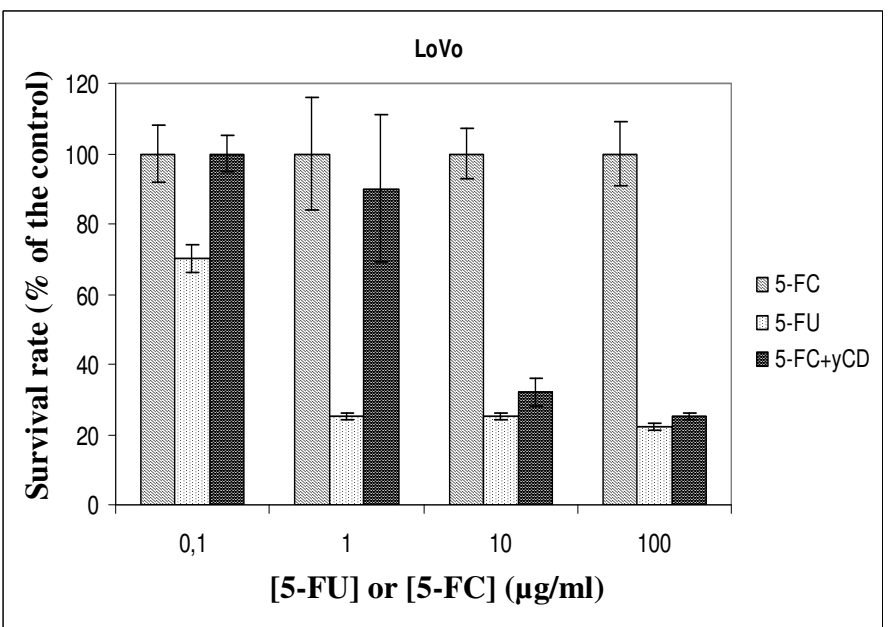

B

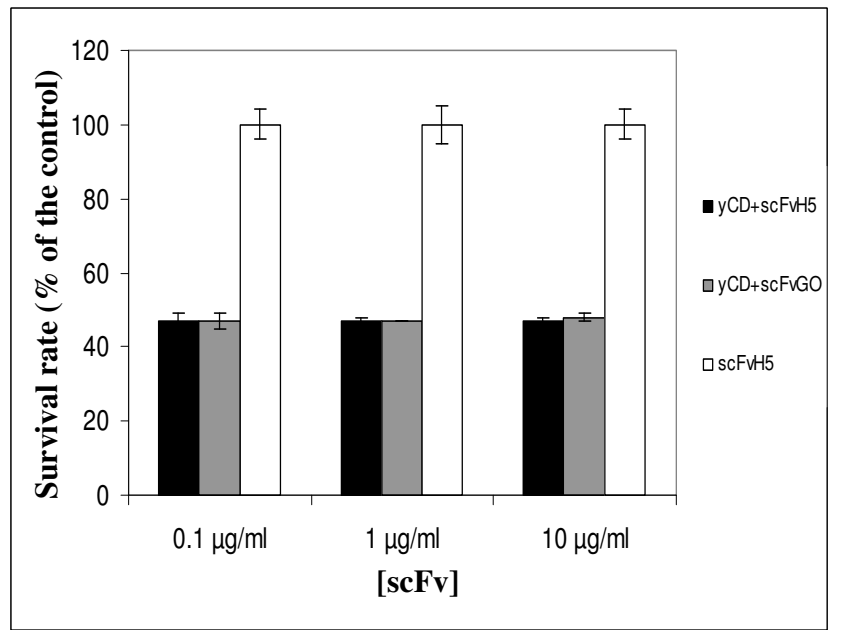

\section{Figure 6}

In in vivo assay of yCD protein. In (A), LoVo cells were seeded in 96-well plate (2500 cells/well) and cultured in BM for 4 days containing $2.5 \mu \mathrm{g} \mathrm{ml^{-1 }}$ of $y C D$ in presence of the indicated concentrations of $5-\mathrm{FC}$. In (B), the cells were culture at same conditions but in BM containing $2.5 \mu \mathrm{g} \mathrm{ml^{-1 }}$ of $y C D$ and $10 \mu \mathrm{g} \mathrm{ml}^{-1}$ of $5-\mathrm{FC}$ in presence of different concentrations of scFvH5 or the irrelevant scFvGO antibodies. Cell cytotoxicity (due to de novo formed 5-FU) was evaluated by WST-I assay and calculated as a percentage of survived cells. Values are reported as the mean of triplicate samples. The bars indicate SD.

chased from Dako (Denmark, EU). 5-Fluorocytosine (5FC) and 5-Fluorouracil (5-FU) were purchased respectively, from Sigma and Mayne Pharma (Naples, Italy, EU)

\section{Vector construction}

Complete yCD gene sequence [18] was amplified by PCR from cDNA inserted in pACCMV 115 . The sense primer was: BamyCD 5'-CGA ATT GGA TCC ATG GTG ACA GGG GGA-3', containing BamHI restriction site and the sequence coding for first five amino acid of $\mathrm{yCD}$. The antisense primer was: ESyCD 5'-ATCC GAT ATC GTC GAC CTC ACC AAT ATC TTC-3' containing the sequences encoding for the end part of $\mathrm{yCD}$ and Sall restriction enzyme.

PCR was performed using Pwo enzyme (Roche Diagnostics; IN, USA) and the resulting PCR fragment was agarose-purified using the High Pure PCR Product Purification Kit (Roche). Then it was digested with restriction enzymes BamHI and SalI, and cloned into the plasmid pQE30Xa (Qiagen; Milan, Italy, EU), containing $6 \times$ His tag sequence for protein purification. The clone was sequenced by Biofab Research SRL (Rome, Italy, EU).

\section{Expression and purification}

TG1 E. coli (supE hsd $\Delta 5$ thi $\Delta$ (lac-proAB) F' [traD36 proAB+ lacIqlacZ $\Delta \mathrm{M} 15]$ ) cells trasformed with plasmid $\mathrm{pQE30Xa}$ yCD were grown in $100 \mathrm{ml} 2 \times$ TY broth supplemented with $100 \mu \mathrm{g} \mathrm{ml}^{-1}$ ampicillin and $0.1 \%$ glucose in a $37^{\circ} \mathrm{C}$ shaker until $\mathrm{OD}_{600}=0.6$. Isopropyl- $\beta$-D-thiogalactopyranoside (IPTG) (Sigma) was added to a final concentration of $1 \mathrm{mM}$. Cells were harvested $3 \mathrm{~h}$ later, centrifuged at $10,000 \mathrm{rpm}$ for $20 \mathrm{~min}$ at $4{ }^{\circ} \mathrm{C}$ and lysed by sonication in lysis buffer $\left(50 \mathrm{mM} \mathrm{NaH} \mathrm{PO}_{4}, 300 \mathrm{mM} \mathrm{NaCl}, 10 \mathrm{mM}\right.$ imidazole, $\mathrm{pH} 8$ ). The yCD protein was purified by affinity chromatography on Ni-NTA resin (Qiagen), using native protocol according to the manufacture instructions. Protein concentration was determined with Fernandez-Patron method. The purified yCD protein was dissolved in PBS, aliquoted and stored at $-80^{\circ} \mathrm{C}$.

\section{NMR}

${ }^{19} \mathrm{~F}$ NMR analyses were performed on BRUKER AVANCE spectrometer (Bruker BioSpin GmbH - Rheinstetten Germany) operating at $9.4 \mathrm{~T}$. The spectra were acquired at $25^{\circ} \mathrm{C}$ with a pulse angle of $60^{\circ}$, interpulse delay of $2 \mathrm{~s}$ and 64 transients. In order to compensate for partial magnetic saturation effect, the correction factors were determined by comparing the measured peak areas with those obtained at equilibrium (flip angle $90^{\circ}$, interpulse delay $30 \mathrm{~s}$ ). At the end of reaction the concentration of 5-FU was determined by adding a known amount of the drug. Spectral analyses were performed utilizing the XWIN-NMR BRUKER suite. ${ }^{19} \mathrm{~F}$-MRS of 3,5 $\mu$ moles of 5 -FC dissolved in $700 \mathrm{ul} \mathrm{D}_{2} \mathrm{O}$ saline buffer was considered the time 0 of the reaction and after $70 \mu \mathrm{l}$ of $25 \mu \mathrm{g} / \mathrm{ml}$ yCD enzyme were 
added. The reaction was followed during $1 \mathrm{~h}$ and $30 \mathrm{~min}$. To verify the complete conversion of 5-FC to 5-FU the last spectrum was acquired at $3 \mathrm{~h}$ and $15 \mathrm{~min}$.

\section{ETH-2 library}

The ETH-2 synthetic human recombinant antibodies library consists of a large array (more than $10^{9}$ antibody combination) of scFv polypeptides displayed on the surface of M13 phage [14]. It was built by random mutagenesis of the CDR3 of only three antibody germline gene segments (DP47 for the heavy chain, DPK22 and DPL16 for the light chain). Diversity of the heavy chain was created by randomizing four to six position, replacing the pre-existing position 95-98 of the CDR3. The diversity of the light chain was created by randomizing six position (96-101) in the CDR3 [15].

\section{Selection of $y C D$ protein specific antibodies from ETH-2 library}

Immunotubes (Nalge Nunc International; NY, US) were coated overnight $(\mathrm{ON})$ at room temperature (RT) with purified yCD in PBS at the concentration of $10 \mu \mathrm{g} \mathrm{ml}^{-1}$. After panning, performed according to Ascione et al. [17], phages were eluted with $1 \mathrm{ml}$ of $100 \mathrm{mM}$ triethylamine, and the solution was immediately neutralized by adding $0.5 \mathrm{ml}$ of $1 \mathrm{M}$ Tris-HCl pH 7.4. Eluted phages were used to infect TG1 $E$. Coli cells and amplified for the next round of selection. Briefly, $50 \mathrm{ml}$ of $2 \times$ TY with $100 \mu \mathrm{g} / \mathrm{ml} \mathrm{amp-}$ icillin and $1 \%$ glucose $(2 \times$ TY-amp-glu $)$ were inoculated with enough bacterial suspension to yield an $\mathrm{OD}_{600 \mathrm{~nm}} \cong$ 0.1 . The culture was grown to $\mathrm{OD}_{600 \mathrm{~nm}}=0.4-0.5$ and infected with K07 helper phage at a ratio of around 20:1 phage/bacteria. The rescued phages were concentrated by precipitation with PEG 6000 and used for the next round of panning. For soluble scFv preparation, cloned E. coli cells were grown for $2 \mathrm{~h}$ at $37^{\circ} \mathrm{C}$ in $180 \mu \mathrm{l}$ of $2 \times$ TY-ampicillin $\left(100 \mu \mathrm{g} \mathrm{ml}^{-1}\right)$ and $0.1 \%$ glucose in 96 -well plates and induced with $50 \mu \mathrm{l}$ of $2 \times$ TY- 6 mM IPTG. The following day the plates were spun down at $1800 \mathrm{~g}$ for $10 \mathrm{~min}$ at $4^{\circ} \mathrm{C}$ and the supernatants containing soluble scFv were recovered and tested for specific yCD recognition in ELISA.

\section{ELISA}

96-well ELISA plates were coated ON with $50 \mu \mathrm{l} /$ well of $10 \mu \mathrm{g} \mathrm{ml}^{-1}$ purified yCD in PBS at $4{ }^{\circ} \mathrm{C}$. Next day a blocking solution, $2 \%$ non-fat milk in PBS (2\% MPBS) was added and after $2 \mathrm{~h}$ the plates were washed with PBS containing $0.05 \%$ Tween 20 (TPBS). Plates were incubated for $2 \mathrm{~h}$ at RT with $50 \mu \mathrm{l}$ of supernatants containing soluble scFv antibodies, anti-Flag M2 antibody and anti-mouse HRP-conjugated antibody. All antibodies were resuspended in $2 \%$ MPBS.
The reaction was developed using 3,3'-5,5'-tetramethylbenzidin BM blue and POD substrate soluble (Roche Diagnostics) and stopped by adding $50 \mu \mathrm{l}$ of $1 \mathrm{M}$ sulfidric acid. The reaction was detected with an ELISA reader (BIORAD; CA, USA) and the results were expressed as OD, i.e. the absorbance per unit length, were absorbance $(A)$ is calculated as $\mathrm{A}=\mathrm{A}(450 \mathrm{~nm})-\mathrm{A}(620 \mathrm{~nm})$.

\section{DNA characterization and sequences}

Plsmidic DNA encoding for selected scFvs were digested by specific endonucleases and CDR3 regions were sequenced with an automated DNA sequencer (M-Medical/Genenco, Pomezia Italy) using fdseq1 (5'-GAA TTT TCT GTA TGA GG-3') and pelBback (5'-AGC CGC TGG ATT GTT ATT AC-3') primers.

\section{Soluble scFv purification}

The clone scFvH5, was cultured for large-scale scFv production. TG1 E. coli infected cells were cultured at $30^{\circ} \mathrm{C}$ in $2 \times$ TY containing $100 \mu \mathrm{g} \mathrm{ml}^{-1}$ ampicillin and $0.1 \%$ glucose up to $\mathrm{OD}_{600}=0.5$. After induction of antibody expression by adding $1 \mathrm{mM}$ IPTG to culture, cells were incubated $\mathrm{ON}$ at $30^{\circ} \mathrm{C}$. Then, the bacterial culture was centrifugated and antibody containing supernatant collected. Antibody fragments were precipitated with ammonium sulfate and dialyzed in PBS. His-tagged scFv fragments were purified by immobilized metal affinity chromatography using $\mathrm{Ni}^{2+}$-nitriloacetic acid agarose (Qiagen). ScFv fragments were eluted with $250 \mathrm{mM}$ imidazole in PBS, dialyzed, ELISA tested for specific antigen recognition, and stored at $-80^{\circ} \mathrm{C}$.

\section{SDS-PAGE and Western Blot analysis}

Purified yCD protein was analyzed on 12\% SDS PAGE gel under reducing conditions. Gel was either stained with Fernandez-Patron method or blotted electrophoretically to nitrocellulose membrane, which was blocked in 5\% MPBS and then washed three times for $10 \mathrm{~min}$ in PBS. For detection of yCD protein, the membrane was incubated either with anti-polyhistidine antibody or with soluble scFvH5. In the first case the membrane was incubated for $2 \mathrm{~h}$ with anti-polyhistidine antibody $1: 1000$ in $2 \% \mathrm{M} / \mathrm{PBS}$ and washed three times with PBS. In the other, the membrane was incubated for $2 \mathrm{~h}$ with soluble scFvs, washed with PBS containing $0.05 \%$ Tween 20 and incubated again with an anti-Flag M2 mouse antibody 1:1000 in 2\% MPBS for $1 \mathrm{~h}$ at RT. In both cases specific binding was detected by HRP-conjugated Goat anti-mouse antibody $1: 1000$ in M/PBS $2 \%$ for $\mathrm{l} h$ at RT. After 3 washings in $2 \%$ $\mathrm{M} / \mathrm{PBS}$, the bound antibodies were visualized with $\mathrm{DAB}$ buffer obtained by dissolving one tabelet $(10 \mathrm{mg}$ ) of 3,3'diaminobenzidine (Sigma) in $20 \mathrm{ml}$ of PBS and $3 \mu \mathrm{l}$ of hydrogen peroxide $30 \%$, for $3 \mathrm{~min}$. The reaction was stopped with $\mathrm{H}_{2} \mathrm{O}$. 


\section{Determination of yCD activity}

The deamination activity of purified $\mathrm{yCD}$ was measured by monitoring conversion of 5-FC to 5-FU in spectrophotometric studies. In $0.5 \mathrm{ml}$ quartz cuvette, $250 \mu \mathrm{l}$ of $1 \mu \mathrm{g}$ $\mathrm{ml}^{-1} \mathrm{yCD}$ was added to solution of $0.36 \mathrm{mM}$ of 5 -FC. The reaction was followed for $30 \mathrm{~min}$ by an UV/Vis spectrophotometer (Beckman DU-64, Beckman Coulter S.p.A., CA, USA) which registered absorbance values every 30 seconds. The absorbance variation was measured at 265 $\mathrm{nm}$, wavelength of the 5-FU maximum UV absorption according to Nishiyama et al., 1985 [17]. Absorbance values were calculated as $\mathrm{A}_{265}(\mathrm{t})-\mathrm{A}_{265}\left(\mathrm{t}_{0}\right),\left(\mathrm{t}_{0}=0 \mathrm{~min}\right)$; the values were converted in concentration of formed 5 -FU, dividing absorbance values by 5-FU molar extinction coefficient at $265 \mathrm{~nm}\left(\varepsilon_{265}\right)$. The calculated 5-FU $\varepsilon_{265}$ was 7 $\mathrm{mM}^{-1} \mathrm{~cm}^{-1}$. Initial velocity of the enzyme was calculated as $\Delta \mathrm{A}_{265} \mathrm{~min}^{-1}$ or as $\Delta[5-\mathrm{FU}] \mathrm{min}^{-1}$ in the first 9 min when the reaction had linear trend.

The same procedures were used in order to examine eventual inhibition of yCD activity occurred in presence of scFvH5. Briefly, $5 \mu \mathrm{l}$ of $200 \mu \mathrm{g} \mathrm{ml}^{-1}$ purified scFvH5 solution were added into the cuvette with yCD and 5-FC. Parallel experiments were performed in presence of the irrilevant scFvGO antibody.

\section{Cytotoxic assay}

The ability of purified yCD protein to convert 5-FC into 5FU was tested in an vitro cell sytem. The human colon adenocarcinoma LoVo cells were maintained in a basic medium (BM) constituted by RPMI 1640 (EuroClone S.p.A; PV, Italy, EU) supplemented with $10 \%$ fetal bovine serum (EuroClone) and 1\% penicillin-streptomycin in humidified atmosphere with $5 \% \mathrm{CO}_{2}$ at $37^{\circ} \mathrm{C}$.

In a cell growth inhibition assay 2500 cells/well were seeded into 96-well microtiter plates (Corning Cable Systems SRL, Turin, Italy, EU) in BM containing $2.5 \mu \mathrm{g} \mathrm{ml}-1$ of yCD and different concentrations of 5-FC. The plates were incubated at $37^{\circ} \mathrm{C}$ for 4 days and cell viability was evaluated by WST-1 assay (Takara, VinciBiochem, Vinci, Florence, Italy, EU).

As positive and negative controls different concentrations of 5-FC and 5-FU alone were used in identical in vitro conditions. A cell growth inhibition assay was also used in order to determine whether the binding with the specific scFvH5 antibody affects yCD enzyme function.

In this experiment LoVo cells (2500 cells/well) were seeded in 96-costar plates in BM containing $2.5 \mu \mathrm{g} \mathrm{ml}^{-1}$ of $\mathrm{yCD}$ and $10 \mu \mathrm{g} \mathrm{ml}^{-1}$ of 5 -FC in presence of scFvH5 or scFvGO antibodies at concentrations ranging from 0.1 to $10 \mu \mathrm{g} \mathrm{ml}-1$. All results were represented as the mean of triplicate samples.

\section{Abbreviations}

5-FC: 5-fluorocytosine; 5-FU: 5-fluorouracil; yCD: yeast cytosine deaminase; scFv: single chain fragment variable; GO: glucose oxidase; mAb; monoclonal antibody

\section{Competing interests}

The authors declare that they have no competing interests.

\section{Authors' contributions}

AM carried out selection of the ETH-2 library against yCD and contributed to the genetic, molecular, and immunobiochemical characterization of scFvs.SZ carried out expression, production and purification of $\mathrm{yCD}$ protein and participated to biopanning selection of the ETH2 library, and biochemical characterization of the antibodies to yCD.MF, AA and MG actively participated to yCD purification and biopanning procedures for $\mathrm{scFv}$ isolation and selection. GC and FS with the supervision of FP conceived, promoted and carried out NMR experiments for the functional assay of the $\mathrm{yCD}$ enzyme. MT carried out the cell culture experiments including the testing of the cell growth and viability in presence of drug. MC conceived and promoted the approach with the ETH-2 phage library to select specific scFv human antibodies against soluble yCD protein. Furthermore, MC participated in the design and coordination of the entire research project. All authors have read and approved the final version of the manuscript.

\section{Acknowledgements}

This work in supported by ISS-NIH and ISS-ACC research grants. SZ is supported by an ISS Research Funds for PhD Fellowship.

\section{References}

I. Kievit E, Bershad E, Ng E, Sethna P, Dev I, Lawrence TS, Rehemtulla A: Superiority of Yeast over Bacterial Cytosine Deaminase for Enzyme/Prodrug Gene Therapy in Colon Cancer Xenografts. Cancer Res 1999, 59:|4|7-|421.

2. Grem JL: 5-Fluorouracil: forty-plus and still ticking. A review of its preclinical and clinical development. Investigational New Drugs 2000, 18:299-313.

3. Guffey MB, Parker JN, Luckett WS Jr, Gillespie GY, Meleth S, Whitley RJ, Markert JM: Engineered herpes simplex virus expressing bacterial cytosine deaminase for experimental therapy of brain tumors. Cancer Gene Ther 2007, I 4(I):45-56.

4. Hedley D, Ogilvie L, Springer C: Carboxypeptidase G2-based gene directed enzyme-prodrug therapy:a new weapon in the GDEPT armoury. Nat Rev Cancer 2007, 7(I I):870-879.

5. Coelho V, Dernedde J, Petrausch U, Panjideh H, Fuchs H, Menzel C, Dubel S, Keilholz U, Thiel E, Deckert PM: Design, construction, and in vitro analysis of $A 33 \mathrm{scFv}:$ :CDy, a recombinant fusion protein for antibody-directed enzyme prodrug therapy in colon cancer. Int I Oncol 2007, 3 I:95 I-957.

6. Wallace PM, MacMaster JF, Smith VF, Kerr DE, Senter PD, Cosand WL: Intratumoral Generation of 5.-Fluorouracil Mediated by an Antibody-Cytosine Deaminase Conjugate in Combination with 5-Fluorocytosine. Cancer Res 1994, 54:2719-2723.

7. Senter PD, Su PCD, Katsuragi T, Sakai T, Cosand WL, HellstrOm I, HellstrOm KE: Generation of 5-fluorouradil from 5-fluorocytosine by monoclonal antibody-cytosine deaminase conjugates. Bioconjug Chem I991, 2(6):447-45I.

8. Gnant MFX, Puhlmann M, Alexander HR Jr, Bartlett DL: Systemic administration of a recombinant vaccinia virus expressing the cytosine deaminase gene and subsequent treatment 
with 5-fluorocytosine leads to tumor-specific gene expression and prolongation of survival in mice. Cancer Res 1999, 59:3396-3403.

9. Napier MP, Sharma SK, Springer CJ, Bagshawe KD, Green AJ, Martin J, Stribbling SM, Cushen N, O'Malley D, Begent RHJ: Antibodydirected Enzyme Prodrug Therapy: Efficacy and Mechanism of Action in Colorectal Carcinomal. Clinical Cancer Research 2000, 6:765-772.

10. Connors TA: The choice of prodrugs for gene directed enzyme prodrug therapy of cancer. Gene Ther 1995, 2:702-9.

II. Greco O, Dachs GU: Gene directed enzyme/prodrug therapy of cancer: historical appraisal and future prospectives. J Cell Physiol 200I, 187:22-36.

12. Yazawa K, Fisher WE, Brunicardi FC: Current Progress in Suicide Gene Therapy for Cancer. World I Surg 2002, 26:783-789.

13. Huber BE, Austin EA, Good SS, Knick VC, Tibbels S, Richards CA: In vivo antitumor activity of 5 -fluorocytosine on human colorectal carcinoma cells genetically modified to express cytosine deaminase. Cancer Res 1993, 53:4619-4626.

14. Viti F, Nilsson F, Demartis S, Huber A, Neri D: Design and use of phage display libraries for the selection of antibodies and enzyme. Methods Enzymol 2000, 326:480-505.

15. Pini A, Viti F, Santucci A, Carnemolla B, Zardi L, Neri P, Neri D: Design and use of a phage display library. Human antibodies with subnanomolar affinity against a marker of angiogenesis eluted from a two-dimensional gel. I Biol Chem 1998, 273:21769-76.

16. Kerr DE, Garrigues US, Wallace PM, Hellstrom KE, Hellstrom I, Senter PD: Application of monoclonal antibodies against cytosine deaminase for the in vivo clearance of a cytosine deaminase immunoconjugate. Bioconjug Chem 1993, 4:353-7.

17. Ascione A, Flego M, Zamboni S, De Cinti E, Dupuis ML, Cianfruglia M: Isolation and characterization of the human monoclonal antibodies $\mathrm{ClO}$ in single chain fragment variable (scFv) format to Glucose Oxidase from Aspergillus niger. Hybrid Hybridomics 2004, 23:380-4.

18. Erbs P, Exinger F, Jund R: Characterization of the Saccharomyces cerevisiae FCYI gene encoding cytosine deaminase and its homologue FCAI of Candida albicans. Curr Genet 1997, 3I:I-6.
Publish with Biomed Central and every scientist can read your work free of charge

"BioMed Central will be the most significant development for disseminating the results of biomedical research in our lifetime. "

Sir Paul Nurse, Cancer Research UK

Your research papers will be:

- available free of charge to the entire biomedical community

- peer reviewed and published immediately upon acceptance

- cited in PubMed and archived on PubMed Central

- yours - you keep the copyright
BioMedcentral 